This Accepted Author Manuscript is copyrighted and published by Elsevier. It is posted here by agreement between Elsevier and University of Brasilia. Changes resulting from the publishing process - such as editing, corrections, structural formatting, and other quality control mechanisms - may not be reflected in this version of the text. The definitive version of the text was subsequently published in [Virus Research, Volume 140, Issue 1-2, March 2008, Pages 1-7, doi:10.1016/j.virusres.2008.10.010].You may download, copy and otherwise use the AAM for non-commercial purposes provided that your license is limited by the following restrictions:

(1) You may use this AAM for non-commercial purposes only under the terms of the CC-BY-NCND license.

(2) The integrity of the work and identification of the author, copyright owner, and publisher must be preserved in any copy.

(3) You must attribute this AAM in the following format: [agreed attribution language, including link to CC BY-NC-ND license + Digital Object Identifier link to the published journal article on Elsevier's ScienceDirect ${ }^{\circledR}$ platform].

Este Manuscrito do Autor Aceito para Publicação (AAM) é protegido por direitos autorais e publicado pela Elsevier. Ele esta disponível neste Repositório, por acordo entre a Elsevier e a Universidade de Brasília. As alterações decorrentes do processo de publicação - como a edição, correção, formatação estrutural, e outros mecanismos de controle de qualidade - não estão refletidas nesta versão do texto. A versão definitiva do texto foi posteriormente publicado em [Virus Research, Volume 140, Número 1-2, Março de 2008, Paginas 1-7

doi:10.1016/j.virusres.2008.10.010]. Você pode baixar, copiar e utilizar de outra forma o AAM para fins não comerciais, desde que sua licença seja limitada pelas seguintes restrições:

(1) Você pode usar este AAM para fins não comerciais apenas sob os termos da licença CC- BYNC-ND.

(2) A integridade do trabalho e identificação do autor, detentor dos direitos autorais e editor deve ser preservado em qualquer cópia.

(3) Tem de atribuir este AAM no seguinte formato: [acordo na linguagem atribuída, incluindo o link para CC BY-NC-ND licença Digital + DOI do artigo publicado na revista Elsevier ScienceDirect ${ }^{\circledR}$ da plataforma]. 


\title{
Characterization of a new Autographa californica multiple nucleopolyhedrovirus (ACMNPV) polyhedra mutant
}

Bergmann Morais Ribeiro

Ana Paula Montenegro Generino

Cláudia Natércia Lima Acacio

Evanguedes Kalapothakis

Sônia Nair Báo

\begin{abstract}
In the very late phase of baculovirus infection, virions are occluded in a crystalline matrix called polyhedra, which is mainly composed of polyhedrin. This protein is highly conserved among baculoviruses and changes in its amino acid sequence may lead to mutant polyhedra. During the purification of an ACMNPV recombinant virus, a mutant virus was isolated. Structural and ultrastrutural analysis by light and transmission electron microscopy (TEM) of insect cells infected with this mutant virus did not show polyhedra formation and differed from the wild-type infection by the presence of a proteinaceous mass dispersed in the cytoplasm and nucleus of the infected cells, which was confirmed by immunogold labelling to be polyhedrin. The polyhedrin gene was amplified by PCR and sequenced. The only change observed was the substitution of a $G$ to a $T$ at the nucleotide +352 , which resulted in a Val to Phe change. A recombinant virus was constructed by transferring the mutant gene into a polyhedrin negative virus. The phenotype of this recombinant virus was the same as the mutant one, confirming that this single mutation alone was responsible for the mutant phenotype.
\end{abstract}

Keywords: Baculovirus; Polyhedrin mutant; Polyhedra; AcMNPV; Insect cells

\section{Introduction}

Baculoviruses are insect viruses used as biological control agents (Moscardi, 1999) and vectors for the expression of heterologous proteins in insect cells in culture and insect larvae (Jarvis, 1997). These viruses have large dsDNA genomes, and enveloped rod-shaped nucleocapsids. The Baculoviridae family is divided into two genera: Nucleopolyhedrovirus (NPV) and Granulovirus (GV) ( Theilmann et al., 2005). The Autographa californica multiple nucleopolyhedrovirus (AcMNPV) is the type species of the NPV genus and is the most studied baculovirus to date.

Baculoviruses produce, during their replication cycle, two phenotypes: the extracellular or budded virus (ECV or BV), responsible for the spread of infection within the insect larvae and the occluded derived virus (ODV), responsible for the infection from insect to insect. The BV is produced early in infection and the ODV is produced late in infection, inside 
the nucleus of infected cells (Harrap, 1972). The ODVs are found occluded in a protein matrix made of a protein called polyhedrin forming occlusion bodies, also called polyhedra (Maruniak, 1986) which are responsible for protecting the virions in the environment before a new susceptible host is infected (Steinhaus, 1960). The polyhedrin protein has a molecular mass of around $29 \mathrm{kDa}$ and it is highly expressed late in infection of insect cells.

Polyhedra formation seems to depend on interactions between polyhedrin and other proteins present on the virions envelope (Woo et al., 1998). However, the polyhedra morphology seems to take into account not only polyhedrin interactions with other viral and or host cell proteins (Woo et al., 1998), but its own amino acid sequence (Carstens et al., 1992, Cheng et al., 1998 and Hu et al., 1999).

Polyhedrin is a highly conserved protein among baculoviruses and amino acid changes in the protein sequence could lead to the formation of mutant viruses with morphologically distinct polyhedra (Smith et al., 1983 and Katsuma et al., 1999). A domain required for supramolecular assembly of the polyhedra has been proposed for AcMNPV's polyhedrin (Jarvis et al., 1991).

Some AcMNPV polyhedra mutants have been isolated and characterized (Brown et al., 1980, Carstens, 1982, Duncan and Faulkner, 1982 and Duncan et al., 1983), with most of them containing point mutations in the polyhedrin gene sequence responsible for the altered phenotype of the polyhedra (Carstens et al., 1986, Carstens et al., 1987, Carstens et al., 1992 and Lin et al., 2000).

In this work, we have isolated and characterized a new polyhedra mutant AcMNPV virus (vSynlitx1B12P) isolated during the construction of a recombinant AcMNPV virus.

\section{Materials and methods}

\subsection{Cells and viruses}

Trichoplusia ni (BTI-Tn-5B1-4 or Tn-5B) cells ( Granados et al., 1994) were grown in TC100 medium (Gibco-BRL) supplemented with $10 \%$ fetal calf serum at $27^{\circ} \mathrm{C}$. This cell line served as host for the in vitro propagation of AcMNPV, the polyhedra mutant virus and the recombinant virus constructed in this work. 


\subsection{Isolation of an AcMNPV polyhedra mutant}

During the isolation of a recombinant AcMNPV virus containing a toxin gene from the spider Loxosceles intermedia (not shown), we isolated a polyhedra mutant virus (vSynlitx1B12P). In brief, the transfer vector pSynXIVVI+X3 (Wang et al., 1991) was used to clone a cDNA from the toxin gene (LiTXX1) from L. intermedia ( De Castro et al., 2004). The recombinant plasmid pSynLitx1 was used in a co-transfection with DNA from the recombinant virus vSynVI-gal DNA ( Wang et al., 1991), previously linearized with the restriction enzyme Bsu36I (New England Biolabs), into a monolayer of Tn-5B cells (106 cells) in a 60-mm plate, using liposomes (Cellfectin ${ }^{\circledR}$, Invitrogen). The plate was incubated 1 week at $27^{\circ} \mathrm{C}$ until the appearance of polyhedra, when the supernatant was collected and used to purify the recombinant virus through end-point dilution in 96-well plates ( O'Reilly et al., 1992). The single Bsu36I site of vSynVI-gal is located inside the $\beta$-galactosidase gene, and linearization makes it non-infective ( Kitts et al., 1990), facilitating recombinant virus purification. Furthermore, the pSynLitx1 plasmid possesses, besides the toxin gene, the polyhedrin gene (disrupted in vSynVI-gal). Upon homologous recombination of plasmid and viral DNA during co-transfection, vSynVI-gal regains expression of polyhedrin, which is made evident by the formation of occlusion bodies by the recombinant virus. During the first round of isolation, using the protocol described by O'Reilly et al. (1992), we noted a well in a 96-well plate containing different cells with few polyhedra and dark patches inside the cytoplasm. The supernatant of this well was collected and used in three rounds of serial dilution for the isolation of the possible mutant virus which was designated vSynlitx1B12P.

\subsection{Isolation, cloning and sequencing of the polyhedrin gene from the mutant virus}

The isolated mutant virus (vSynlitx1B12P) was amplified in Tn-5B cells $(5 \times 106$ cells) in a 100-mm plate (TPP), purified by ultracentrifugation and its DNA extracted following the methodology described by O'Reilly et al. (1992). The vSynlitx1B12P DNA was then used in a PCR reaction with specific oligonucleotides (ORF603 5'-CAGCCATTGTAATGAGACGC-3' and AcpolR 5'-CAACAACGCACAGAATCTAG-3') for the amplification of the polyhedrin gene. The ORF603 primer anneals at 162 nucleotides upstream from the start codon of polyhedrin gene and the AcpolR primer anneal at 37 nucleotides downstream of the polyhedrin stop codon. The amplified PCR fragment was cloned into the PGEM-T vector following the manufacturer's instructions (Promega), completely sequenced (ABI-PRISM) and the sequences analyzed using 
the open reading frame finder (ORF finder) and BLAST programs (Altschul et al., 1990) at the NCBI home page (http://www.ncbi.nlm.nih.gov).

\subsection{Construction of a recombinant ACMNPV with the mutated polyhedrin gene}

The plasmid containing the polyhedrin gene from vSynlitx1B12P (pGEMPOL) and the transfer vector pSynXIVVI+X3 were digested with the Kpnl and BamHI restriction enzymes, separated by electrophoresis in a 0.8\% agarose gel (Sambrook et al., 1989). A 460 and 5000 bp fragments from pGEMPOL and pSynXIVVI+X3, respectively, were purified from the gel using the GFX band prep kit following the manufacturers' instructions (GE healthcare), ligated and used to transform Escherichia coli DH5- $\alpha$ cells using standard protocols ( Sambrook et al., 1989). The recombinant plasmid pSynpolmut was isolated, mixed with vSynVI-gal DNA and transfected into $\mathrm{Tn}-5 \mathrm{~B}$ cells as described above. The recombinant virus containing the mutant polyhedrin gene (vSynpolmut) was then isolated by end point dilution as previously described.

\subsection{SDS-PAGE and Western blot}

Tn-5B cells were seeded at $1 \times 106$ cells per well in six-well plates, mock infected and infected with wild type, vSynVI-gal, vSynlitx1, vSynlitx1B12P and vSynpolmut viruses. Cells were harvested at 72 h.p.i. and centrifuged at $750 \times \mathrm{g}$ for $7 \mathrm{~min}$. The pellet was washed in PBS and boiled for $5 \mathrm{~min}$ in SDS sample buffer (ESB: $0.0625 \mathrm{M}$-Tris $\mathrm{HCl}, \mathrm{pH} 6.8,1 \%$ SDS, 2\% 2mercaptoethanol, $10 \%$ glycerol and $0.001 \%$ bromophenol blue). Protein samples were subjected to two $12 \%$ SDS polyacrylamide gels using a Mini-Protean apparatus and following the manufacturer's instructions (Bio-Rad). After electrophoresis, one gel was stained in a mixture of acetic acid:methanol:water (10:40:50) containing 0.1\% Coomassie brilliant blue and destained in the same solution without Coomassie brilliant blue. The proteins present in the other gel were blotted onto a nitrocellulose membrane (GE Healthcare) using the Trans-Blot SD device, following the manufacturer's instructions (Bio-Rad). The polyhedrin protein was detected using a rabbit polyclonal antibody raised against the AcMNPV polyhedrin using standard methodology ( Alves Júnior et al., 2008). In brief, the membranes were incubated for $1 \mathrm{~h}$ in $1 \%$ non-fat powdery milk in PBS-T [1× PBS (10 mM): $0.23 \mathrm{~g} \mathrm{NaH2PO} 4$ (anhydrous; 1.9 mM phosphate), $1.15 \mathrm{~g}$ Na2HPO4 (anhydrous; $8.1 \mathrm{mM}$ phosphate), $8.75 \mathrm{~g} \mathrm{NaCl}$ (150 mM Na+), pH 7.2 in 1 I of water] plus $0.5 \%$ Tween 20 , and then $1 \mathrm{~h}$ in anti-polyhedrin (1:2000) in $0.5 \times$ PBS. After washing the membranes three times in 5 -min steps with $0.5 \times$ PBS, they were 
incubated with 1:10,000 (v/v) goat anti-rabbit IgG alkaline phosphatase conjugate in $0.5 \times$ PBS for $1 \mathrm{~h}$. The washing steps were repeated and NBT/BCIP (Sigma) substrate ( $33 \mathrm{ml}$ of a $5 \%$ solution in DMF of NBT and $22 \mathrm{ml}$ of a $5 \%$ solution in 70\% DMF) in $7.5 \mathrm{ml}$ of $0.1 \mathrm{M}$ Tris buffer, $\mathrm{pH}$ 9.5, containing $0.1 \mathrm{M} \mathrm{NaCl}$ and $5 \mathrm{mM} \mathrm{MgCl}$, was added to develop the reaction ( Sambrook et al., 1989).

\subsection{Structural, ultrastructural and immunogold labelling analysis of infected cells}

Sixty millimeter-plates were seeded with Tn-5B cells $(1 \times 106)$ and infected with wildtype, mutant and recombinant viruses (10 pfu/cell). At 72 h.p.i., insect cells were observed and photographed in a light Axiophot microscope (Zeiss) and processed for electron microscopy. In brief, samples were fixed for $30 \mathrm{~min}$ (2\% glutaraldehyde, 2\% paraformaldehyde in $0.1 \mathrm{M}$ sodium cacodylate buffer $\mathrm{pH} 7.4$ with $5 \%$ sucrose), centrifuged at $750 \times \mathrm{g}$ for $5 \mathrm{~min}$, the pellet washed in the same buffer, post-fixed ( $1 \%$ osmium tetroxide, $0.8 \%$ potassium ferricyanide in the same buffer), contrasted in block with $0.5 \%$ uranyl acetate, dehydrated in acetone, and embedded in Spurr's resin. The ultrathin sections were contrasted with uranyl acetate/lead citrate and observed in a TEM JEOL 100C and JEOL 1011 at $80 \mathrm{kV}$. For immunogold labelling, the cells were fixed for $2 \mathrm{~h}$ ( $0.5 \%$ glutaraldehyde, $4 \%$ paraformaldehyde, $0.01 \%$ picric acid, $5 \%$ sucrose in $0.1 \mathrm{M}$ sodium cacodylate buffer $\mathrm{pH}$ 6.4), washed twice in $0.1 \mathrm{M}$ sodium cacodylate buffer $\mathrm{pH} 6.4$, incubated with $50 \mathrm{mM}$ ammonium chloride for $1 \mathrm{~h}$ at $4{ }^{\circ} \mathrm{C}$, and washed twice in distilled $\mathrm{H} 2 \mathrm{O}$. The samples were then contrasted in block with $2 \%$ uranyl acetate overnight (in the dark) at $4{ }^{\circ} \mathrm{C}$, washed twice in distilled $\mathrm{H} 2 \mathrm{O}$ and dehydrated in acetone and embedded in LRGold resin for $72 \mathrm{~h}$ at $-20^{\circ} \mathrm{C}$, under UV light. The detection of the polyhedrin protein in ultrathin sections was performed as described by Van Lent et al. (1990) using a rabbit polyclonal antibody (dilution 1:50) raised against the AcMNPV polyhedrin as described above. The samples were then visualized in a TEM JEOL 1011 at $80 \mathrm{kV}$.

\section{Results}

\subsection{Isolation of a polyhedra mutant AcMNPV}

During the isolation of a recombinant AcMNPV virus carrying the spider L. intermedia LiTXX1 toxin gene ( Fig. 1B) we detected infected insect cells with an altered phenotype showing dark patches inside the cytoplasm late in infection. We then isolated a mutant virus 
(vSynlitx1B12P) by three rounds of serial dilutions in 96-well plate that produced few or no polyhedra late in infection and showed a granular material dispersed inside the cytoplasm and nuclei of infected cells (not shown).

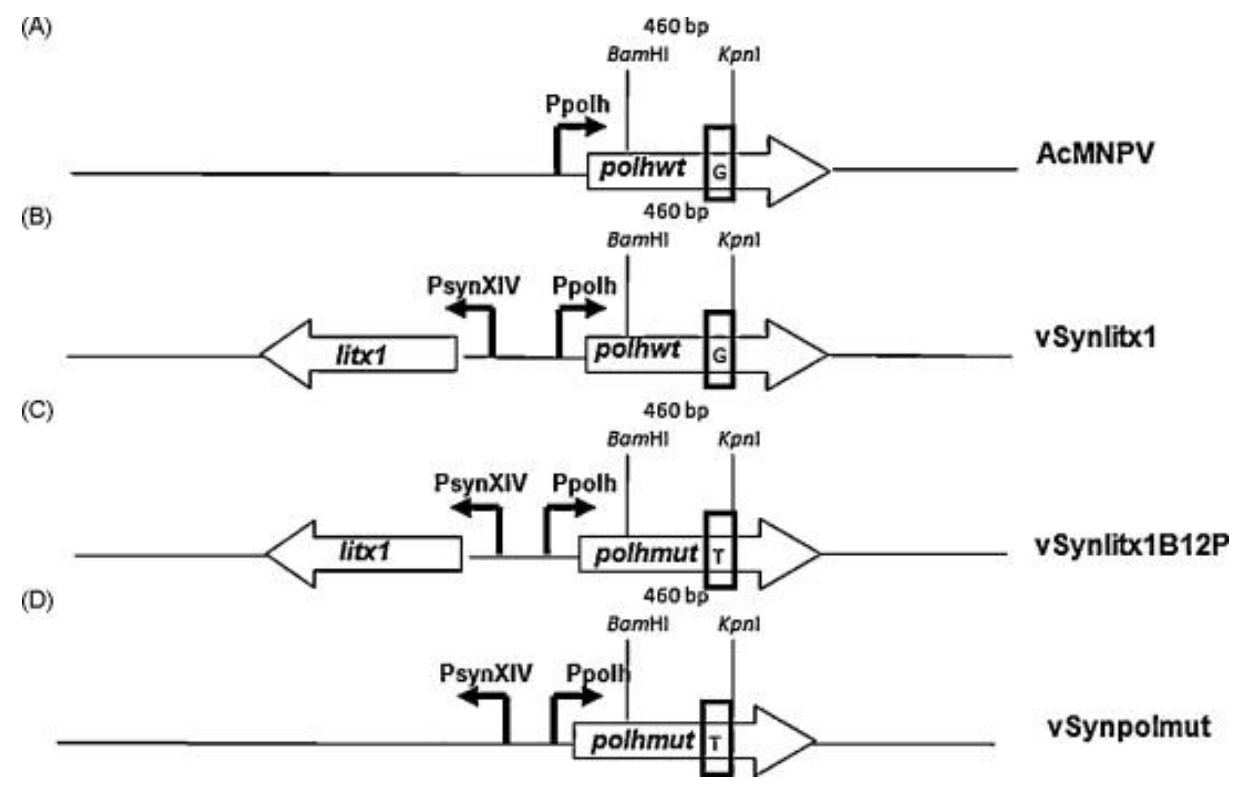

Fig. 1. Diagram showing the polyhedrin gene locus from the viruses used in this work. (A) Wild-type AcMNPV, (B) recombinant vSynLtx1, (C) mutant vSynLtx1B12P, and (D) recombinant vSynpolmut. polhwt: polyhedrin gene, polhmut: mutated polyhedrin gene, litx1: Spider L. intermedia litX×1 gene, Ppolh: polyhedrin promoter, PsynXIV: hybrid promoter containing a mutated promoter derived from polyhedrin promoter (PXIV) and a synthetic promoter (PSyn) in tanden (Wang et al., 1991). The rectangle inside the polhwt and polhmut genes show the nucleotide at position +352 . Above the polhwt and polhmut genes are shown the position of the BamHI and Kpnl restriction sites. This region (460 bp) was removed from the polhmut gene and used to replace the same fragment in the polhwt sequence present in the transfer vector PSynXIVVI+X3. The modified vector was then used for the construction of the recombinant vSynpolmut.

\subsection{Cloning and sequencing of the mutant polyhedrin gene}

The polyhedrin gene of the vSynlitx1B12P was amplified by PCR (not shown), cloned and sequenced (not shown). The sequence of the polyhedrin gene showed a single difference from the wild-type gene. A change from a $\mathrm{G}$ to a $\mathrm{T}$ at position +352 (related to the start codon) which resulted in a single amino acid change from Val to Phe at amino acid position 118 (Fig. $1 \mathrm{~A}$ and $\mathrm{C})$.

\subsection{Construction of a recombinant AcMNPV with the mutated polyhedrin gene}

A fragment of 460 nucleotides from the wild-type polyhedrin gene present in the transfer vector PSynXIVVI+X3 was replaced by the corresponding fragment from the mutated polyhedrin gene which contains the mutation at position +352 of the vSynlitx1B12P. This new 
plasmid pSynpolmut was co-transfected with DNA from the vSynVI-gal and a recombinant virus (vSynpolmut) containing the polyhedrin mutant gene was isolated (Fig. 1D).

\subsection{Structural, ultrastructural and immunogold labelling analysis of virus-infected cells}

The wild-type AcMNPV and vSynlitx1 recombinant virus-infected Tn-5B cells showed very similar cytopathic effects, with the presence of polyhedra inside nuclei at 72 h.p.i. (Fig. $2 \mathrm{~A}-\mathrm{C})$. On the other hand, the recombinant vSynpolmut showed the same cytopathic effects in $\mathrm{Tn}-5 \mathrm{~B}$ cells late in infection as the mutant vSynlitx1B12P (compare Fig. 2D-F), confirming that the mutant phenotype was due to the single mutation in the polyhedrin gene sequence. The mutant virus had no or few polyhedra late in infection and showed a granular material dispersed inside the cytoplasm and nuclei of infected cells (Fig. 2 and Fig. 3). Enveloped virions were observed and no or few polyhedra formation could be detected (Fig. 3A-D). All other cytopathic effects of a normal baculovirus infection were detected, such as rounding of cells (Fig. 2E and F) and the presence P10 fibrillar aggregates inside the cytoplasm and nuclei of infected cell (Fig. 3A-D) To verify if this material dispersed in the cell was the polyhedrin protein, cells infected with the mutant virus were prepared for immunogold labelling and analysed by TEM. The result showed (Fig. 4) that the antibody against polyhedrin was specific to polyhedrin since it bounded to polyhedra from AcMNPV-infected cells (Fig. 4 inset) and to granular material inside the cytoplasm and nucleus of vSynlitx1B12P-infected cells (Fig. 4A and B). 

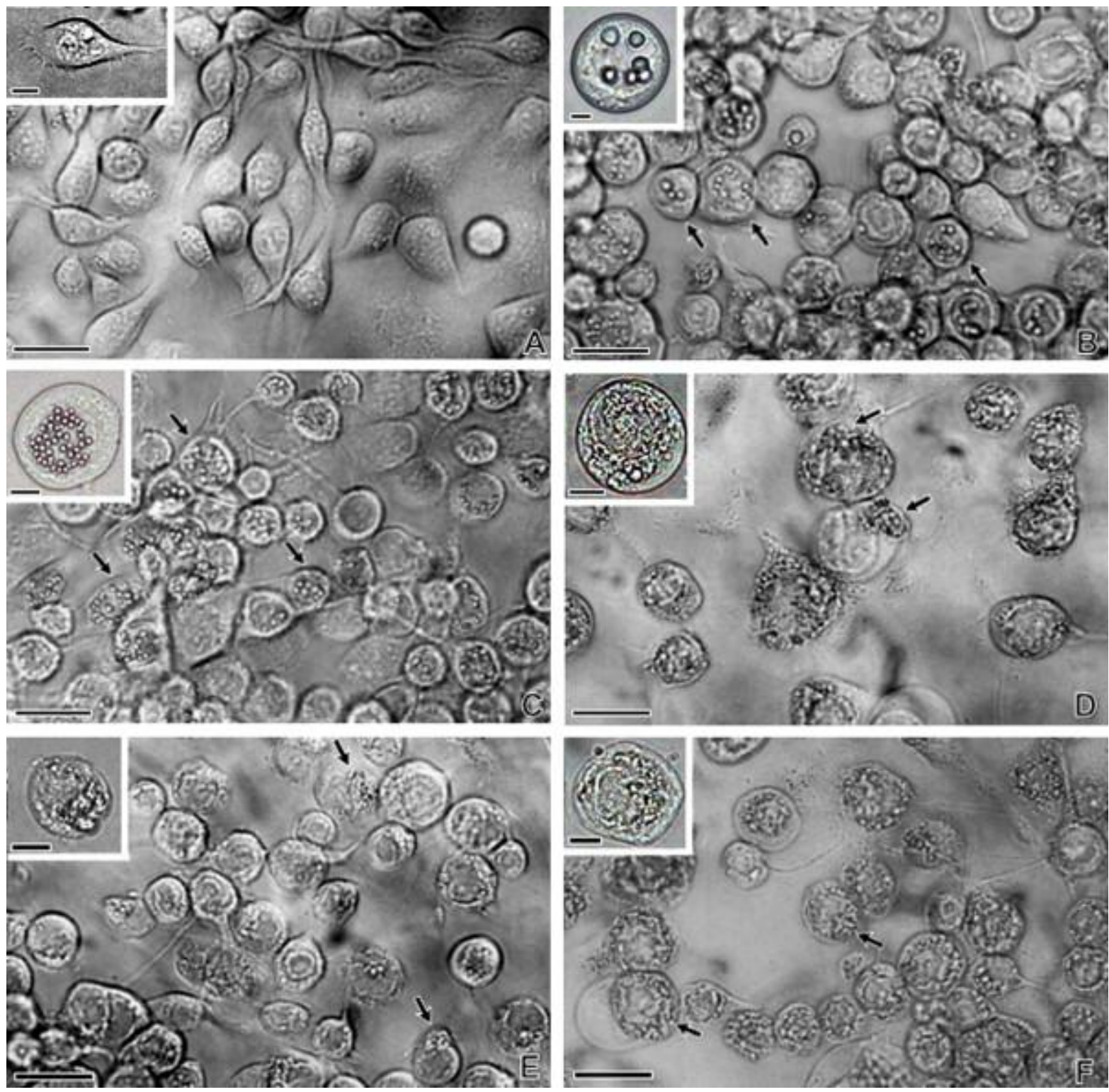

Fig. 2. Structural analysis of wild-type and mutant baculovirus-infected Tn-5B cells. (A) Mock-infected cells, (B) AcMNPV-infected cells 72 h.p.i., (C) vSynlitx1-infected cells 72 h.p.i., (D) vSynpolmut-infected cells 72 h.p.i., (E and F) vSynLtx1B12P-infected cells at 48 and 72 h.p.i., respectively. Arrows show polyhedra inside nuclei of infected cells ( $B$ and $C$ ) and amorphous material inside mutant (vSynLtx1B12P) and recombinant virus (vSynpolmut)-infected cells. Insets show details of a single cell from each treatment. Bars $=30$ and $10 \mu \mathrm{m}$ (insets). 

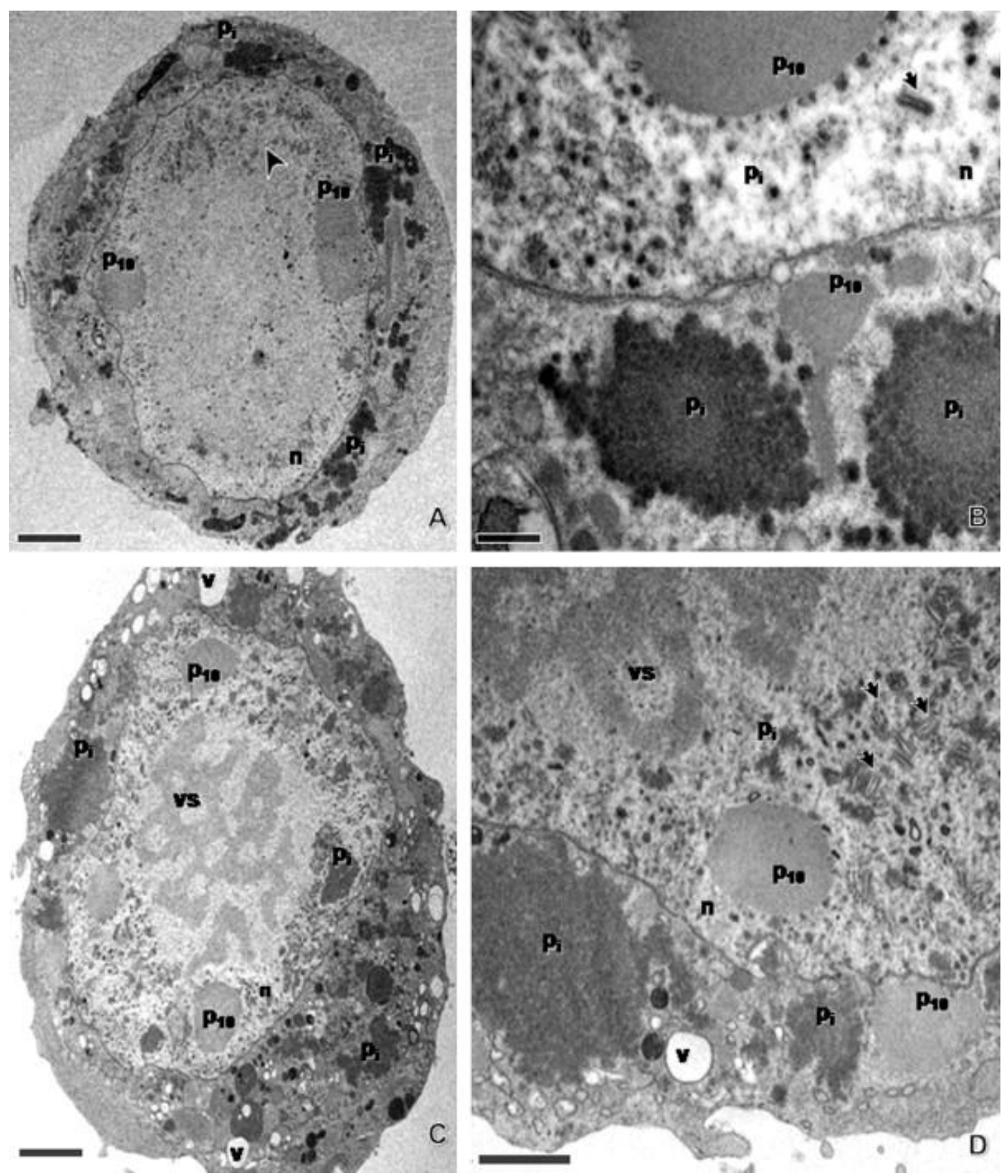

Fig. 3. Ultrastructural analysis of vSynLtx1B12P-infected Tn-5B cells at 72 h.p.i. (A and B) and 96 h.p.i. (C and $\mathrm{D})$. $\mathrm{n}$ : nucleus, vs: virogenic stroma, $\mathrm{Pi}$ : polyhedrin, $\mathrm{P} 10$ : fibrillar material from the baculovirus $\mathrm{P} 10$ protein and v: vacuole. Arrow heads show nucleocapsids. Note that the polyhedrin (Pi) protein is dispersed inside nucleus and cytoplasm of infected cells. Bars $=2 \mu \mathrm{m}(\mathrm{A}$ and $\mathrm{C}), 0.5 \mu \mathrm{m}(\mathrm{B})$ and $1 \mu \mathrm{m}(\mathrm{D})$. 


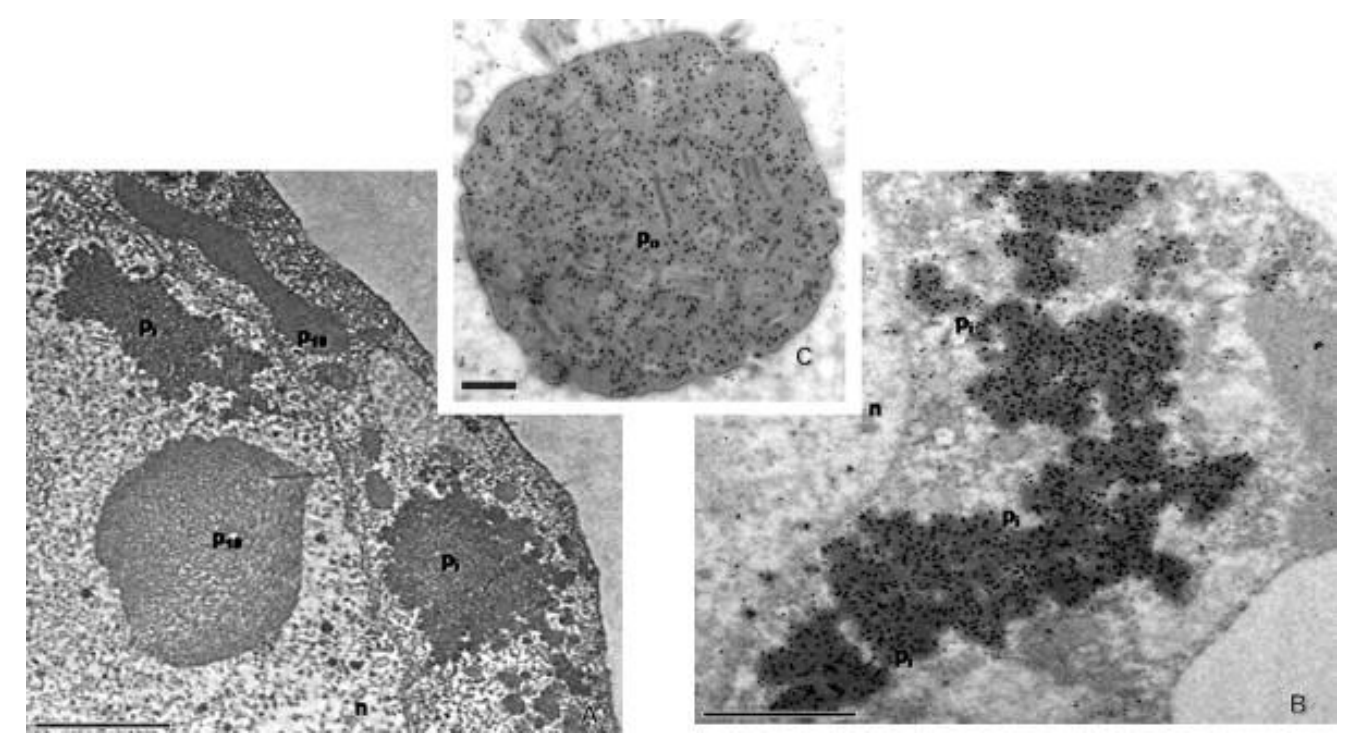

Fig. 4. Immunogold labelling of polyhedrin in vSynLtx1B12P-infected Tn-5B cells at 72 h.p.i. (A) vSynLtx1B12P-infected Tn-5B cells incubated with only an anti-rabbit IgG conjugated with gold particles at 1:20 dilution. (B and C) vSynLtx1B12P- and AcMNPV-infected Tn-5B cells incubated with the antipolyhedrin antibody diluted 1:50 followed by incubation with anti-rabbit IgG conjugated with gold particles at 1:20 dilution, respectively. $\mathrm{n}$ : nucleus, Po: polyhedra, Pi: polyhedrin and P10: fibrillar material from the baculovirus $\mathrm{P} 10$ protein. Bars $=1 \mu \mathrm{m}(\mathrm{A}$ and $\mathrm{E})$ and $0.2 \mu \mathrm{m}(\mathrm{C})$.

\subsection{SDS-PAGE and Western blot analysis}

In order to confirm the presence of the polyhedrin protein in insect cells infected with the mutant, wild-type and recombinant viruses, infected insect cells extracts were analysed by SDS-PAGE and Western blot. All virus-infected insect cells extracts used showed a 29 kDa band by SDS-PAGE (Fig. 5A), which correspond to the polyhedrin protein. Furthermore, these protein bands were also detected by a rabbit polyclonal antibody raised against the AcMNPV polyhedrin (Fig. 5B).

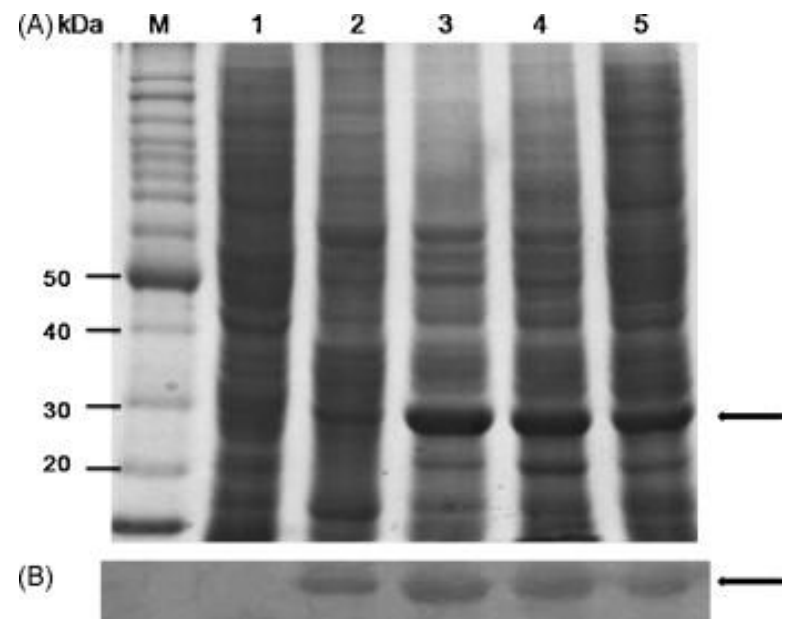

Fig. 5. Expression analysis of polyhedrin in insect cells infected with the mutant vSynLtx1B12P. (A) SDSPAGE (12\%) showing in M: molecular weight marker (Bench Mark, Invitrogen), (1) mock-infected Tn-5B cell extract, (2) AcMNPV-infected Tn-5B cell extract, (3) vSynLtx1-infected Tn-5B cell extract, (4) vSynLtx1B12P-infected Tn-5B cell extract and (5) vSynpolmut-infected Tn-5B cell extract. (B) Western blot of a membrane containing Tn-5B cell extracts similar to the ones shown in (A). Note that a $29 \mathrm{kDa}$ 
protein band was detected in all virus-infected insect cells extracts with a polyhedrin-specific antibody (arrows).

Table 1

List of AcMNPV and BmNPV polyhedra mutant viruses and position of amino acid changes in polyhedrin protein

\begin{tabular}{lllll}
\hline Mutant name/parental virus & Amino acid position (wt/mutant) & Occlusion & Occlusion morphology & Reference \\
\hline AcMNPV-Tkmt513/AcMNPV & 25(Gly/Asp) & OCC $^{+}$ & Large and cuboid with no or few virus occlusion & Lin et al. (2000) \\
M5/AcMNPV & 59 (Pro/Leu) & OCC $^{+}$ & Large and cuboid with no or few virus occlusion & Carstens et al. (1986) \\
\#220/BmNPV & 58 (Asp/Asn), 222 (Ile/Thr) & OCC $^{+}$ & Large and cuboid with no or few virus occlusion & Katsuma et al. (1999) \\
M29/AcMNPV & 85 (Leu/Pro) & OCC $^{-}$ & Dispersed protein mass & Carstens et al. (1987) \\
vSynlitx1B12P/AcMNPV & 118 (Val/Phe) & OCC $^{-}$ & Dispersed protein mass & This work \\
\#136/BmNPV & 141 (Leu/Phe) & OCC $^{-}$ & Dispersed protein mass & Katsuma et al. (1999) \\
\#211/BmNPV & 144 (Glu/Leu) & OCC $^{+}$ & Irregularly shaped or small & Katsuma et al. (1999) \\
\#128/BmNPV & 171 (Leu/Pro) & OCC $^{+}$ & As wild-type occlusion with no or few virus occluded & Katsuma et al. (1999) \\
\#126/BmNPV & $178($ Cys/Tyr) & OCC $^{-}$ & Dispersed protein mass & Katsuma et al. (1999) \\
M934/AcMNPV & 183 (Leu/Phe) & OCC $^{-}$ & Dispersed protein mass & Carstens et al. (1992) \\
\hline
\end{tabular}

Wt: wild type, OCC+: occlusion positive and OCC-: occlusion negative.

\section{Discussion}

We have mapped a polyhedrin mutation in the AcMNPV mutant virus vSynlitx1B12P to nucleotide +352 ( $G$ to T change), which resulted in a Val to Phe change at amino acid position 118 . This mutation resulted in the formation of few or no polyhedra and accumulation of a dispersed granular protein mass mainly in the cytoplasm of infected cells. Carstens et al. (1987) have shown that a point mutation at position +253 of the AcMNPV polyhedrin, which changed amino acid 85 (Leu to Pro), was responsible for the polyhedra morphology mutant M29 which showed copious amounts of small particles inside the infected cell nuclei with lacked a crystalline lattice. Carstens et al. (1992) characterized an AcMNPV polyhedrin mutant (M934), which had a mutation that changed amino acid 183 (Leu to Phe), and showed no polyhedra formation and roughly crescent-shaped inclusions located in a ring just within nuclear boundary. Katsuma et al. (1999) characterized Bombyx mori nucleopolyhedrovirus (BmNPV) polyhedra mutants \#126 and \#136 that showed a similar phenotype to the mutant virus characterized in this work with single amino acid changes at positions 178 and 141, respectively. They formed no polyhedra and particles presumed to be composed of polyhedrin were aggregated in the nuclei and cytoplasm of infected cells. Table 1 shows the position of different amino acid changes in the polyhedrin protein from different AcMNPV and BmNPV mutant viruses.

Jarvis et al. (1991) mapped a region between amino acids 19 and 110 in AcMNPV's polyhedrin and proposed that it is required for supramolecular assembly of polyhedra inside the infected cell nucleus. This can be partially confirmed by the existence of a mutant virus with an amino acid mutation within this domain that presents no polyhedra (Carstens et al., 1987). This mutant has a Leu to Pro substitution at amino acid position 84 and great amounts of small polyhedrin particles which lack a crystalline lattice dispersed in the nuclei of infected cells. However, the point mutation found in the AcMNPV polyhedrin gene in the mutant described in this work and in other mutants (Carstens et al., 1992 and Katsuma et al., 1999) showed that these mutant viruses produced few or no polyhedra even though mutations were 
outside the supramolecular assembly domain proposed by Jarvis et al. (1991), suggesting that mutations in highly conserved regions within the polyhedrin are more likely to be responsible for polyhedra mutant viruses, not within a linear defined domain.

Different nucleopolyhedroviruses have morphologically different polyhedra ( Cheng et al., 1998 and Hu et al., 1999). However, the formation of any kind of viral polyhedra seems to depend on specific interactions between molecules of polyhedrin itself ( Carstens et al., 1992 and Cheng et al., 1998) and polyhedrin with host cell and viral factors (Woo et al., 1998). Cheng et al. (1998) replaced the polyhedrin gene of AcMNPV, whose occlusion bodies (OBs) are polyhedral, by the polyhedrin gene of Thysanoplusia orichalcea nucleopolyhedrovirus (ThorNPV), which produces tetrahedral OBs, and showed that tetrahedral polyhedra with properly occluded virions were produced. On the other hand, Eason et al. (1998) replaced the polyhedrin gene of AcMNPV with the granulin gene of Trichoplusia nigranulosis virus (TnGV) and showed the formation of large cuboidal inclusions in the cytoplasm and nucleus of infected insect cells with few virions occluded. Therefore, the polyhedrin and granulin protein sequences are important in determining $O B$ shape but, specific interactions occur between polyhedrin and granulin and other viral proteins in order to facilitate normal virion occlusion and occlusion body assembly and shape in baculoviruses. The fact that single mutations within the polyhedrin gene can lead to mutant viruses with morphologically distinct polyhedra when compared to the wild type ( Carstens et al., 1986, Carstens et al., 1987, Carstens et al., 1992 and Lin et al., 2000) shows the importance of polyhedrin primary structure to the polyhedra correct assembly.

\section{Acknowledgements}

This work was supported by the following Brazilian agencies: PRONEX, FAPDF, CNPq, FINATEC, FINEP and CAPES.

\section{REFERENCES}

Altschul, S.F., Gish, W., Miller, W., Myers, E.W., Lipman, D.J., 1990. Basic local alignment search tool. J. Mol. Biol. 215, 403-410.

Alves Júnior, M., Marraccini, F.M., Melo Filho, P.A., Dusi, A.N., Pio-Ribeiro, G., Ribeiro, B.M., 2008. Recombinant expression of Garlic virus C (GARV-C) capsid protein in insect cells and its potential for the production of specific antibodies. Microbiol. Res. 163, 354-361.

Brown, N., Faulkner, P., Chung, K.L., 1980. Characterization of two morphology mutants of Autographa californica nuclear polyhedrosis virus with large cuboidal inclusion bodies. J. Gen. Virol. 50, 309-316.

Carstens, E.B., 1982. Mapping the mutation site of an Autographa californica nuclear polyhedrosis virus polyhedron morphology mutant. J. Virol. 43, 809-818. 
Carstens, E.B., Krebs, A., Gallerneault, C.E., 1986. Identification of an amino acid essential to the normal assembly of Autographa californica nuclear polyhedrosis virus polyhedra. J. Virol. 58, 684-688.

Carstens, E.B., Lin-bai, Y., Faulkner, P., 1987. A Point mutation in the polyhedron gene of a baculovirus, Autographa californica MNPV, prevents crystallization of occlusion bodies. J. Gen. Virol. 68, 901-905.

Carstens, E.B., Williams, G.V., Faulkner, P., Partington, S., 1992. Analysis of polyhedral morphology mutants of Autographa californica nuclear polyhedrosis virus; molecular and ultrastructural features. J. Gen. Virol. 73, 1471-1479.

Cheng, X., Carner, G.R., Fescemyer, H.W., 1998. Polyhedrin sequence determines the tetrahedral shape of occlusion bodies in Thysanoplusia orichalcea singlenucleocapsid nucleopolyhedrovirus. J. Gen. Virol. 79, 2549-2556.

De Castro, C.S., Silvestre, F.G., Araújo, S.C., de Gabriel, M.Y., Mangili, O.C., Cruz, I., Chávez-Olórtegui, C., Kalapothakis, E., 2004. Identification and molecular cloning of insecticidal toxins from the venom of the brown spider Loxosceles intermedia. Toxicon 44, 273-280.

Duncan, R., Faulkner, P., 1982. Bromodeoxyuridine-induced mutants of Autographa californica nuclear polyhedrosis virus defective in occlusion body formation. J.Gen. Virol. 62, 369-373.

Duncan, R., Chung, K.L., Faulkner, P., 1983. Analysis of a mutant of Autographa californica nuclear polyhedrosis virus with a defect in the morphogenesis of the occlusion body macromolecular lattice. J. Gen. Virol. 64, 1531-1542.

Eason, J.E., Hice, R.H., Johnson, J.J., Federici, B.A., 1998. Effects of substituting granulin or a granulinpolyhedrin chimera for polyhedrin on virion occlusion and polyhedral morphology in Autographa californica multinucleocapsid nuclear polyhedrosis virus. J. Virol. 72, 6237-6243.

Granados, R.R., Guoxun, L., Derksen, A.C.G., McKenna, K.A., 1994. A new insect cell line from Trichoplusia ni (BTI-Tn-5B1-4) susceptible to Trichoplusia ni single enveloped nuclear polyhedrosis virus. J. Invertebr. Pathol. 64, 260-266.

Harrap, K.A., 1972. The structure of nuclear polyhedrosis viruses. Virology 50, 114-123.

Hu, Z.H., Luijckx, T., van Dinten, L.C., van Oers, M.M., Hajos, J.P., Bianchi, F.J.J.A., van Lent, J.W.M., Zuidema, D., Vlak, J.M., 1999. Specificity of polyhedrin in the generation of baculovirus occlusion bodies. J. Gen. Virol. 80, 1045-1053.

Jarvis, D.L., Bohlmeyer, D.A., Garcia, A.J., 1991. Requirements for nuclear localization and supramolecular assembly of a baculovirus polyhedrin protein. Virology 185, 759-810.

Jarvis, D.L., 1997. Baculovirus expression vectors. In: Miller, L.K. (Ed.), The Baculovirus. Plenum Press, New York, pp. 341-389.

Katsuma, S., Noguchi, Y., Shimada, T., Nagata, M., Kobayashi, M., Maeda, S., 1999. Molecular characterization of baculovirus Bombyx mori nucleopolyhedrovirus polyhedron mutants. Arch. Virol. $144,1275-1285$.

Kitts, P.A., Ayres, M.D., Possee, R.D., 1990. Linearization of baculovirus DNA enhances the recovery of recombinant virus expression vectors. Nucl. Acids Res. 18, 5667-5672.

Lin, G.Y., Zhong, J., Wang, X.Z., 2000. Abnormal formation of polyhedra resulting from a single mutation in the polyhedrin gene of Autographa californica nucleopolyhedrovirus. J. Invertebr. Pathol. 76, 13-19. 
Maruniak, J.E., 1986. Baculovirus structural proteins and proteins synthesis. In: Granados, R.R., Federici, B.R. (Eds.), The Biology of Baculoviruses, vol. I. Biological Properties and Molecular Biology. CRC Press, Boca Raton, pp. 29-146.

Moscardi, F., 1999. Assessment of the application of baculoviruses for control of Lepidoptera. Annu. Rev. Entomol. 44, 257-289.

O’Reilly, D.R., Miller, L.K., Luckow, V.A., 1992. Baculovirus Expression Vectors: A Laboratory Manual. Freeman, New York.

Sambrook, J., Fritsch, E.F.,Maniatis, T., 1989.Molecular Cloning: A LaboratoryManual, 2nd ed. Cold Spring Harbor Laboratory Press, Cold Spring Harbor, New York.

Smith, G.E., Fraser, M.J., Summers, M.D., 1983. Molecular engineering of the Autographa californicanuclear polyhedrosis virus genome: deletionmutations within the polyhedrin gene. J. Virol. 46, 584-593.

Steinhaus, E.A., 1960. The duration of viability and infectivity of certain insect pathogens. J. Insect Pathol. 2, 225-229.

Theilmann, D.A., Blissard, G.W., Bonning, B., Jehle, J.A., O’Reilly, D.R., Rohrmann, G.F., Thiem, S., Vlak, J.M., 2005. Baculoviridae. In: Fauquet, C.M., Mayo, M.A., Maniloff, J., Desselberger, U., Ball, L.A. (Eds.), Virus Taxonomy-Eighth Report of the International Committee on Taxonomy of Viruses. Springer, New York, pp. 1129-1185.

Van Lent, J.W.M., Groenen, J.T.M., Klinge-Roode, E.C., Rohrmann, G.R., Zuidema, D., Vlak, J.M., 1990. Localization of the 34-kDa polyhedral envelope protein in Spodoptera frugiperda cells infected with Autographa californica nuclear polyhedrosis virus. Arch. Virol. 111, 103-114.

Wang, X., Ooi, B.G.,Miller, L.K., 1991. Baculovirus vectors formultiple gene expression and for occluded virus production. Gene 100, 131-137.

Woo, S.D., Kim, W.J., Kim, H.S., Jin, B.R., Lee, Y.H., Kang, S.K., 1998. The morphology of the polyhedra of a host range-expanded recombinant baculovirus and its parents. Arch. Virol. 143, 1209-1214. 